\title{
Çalışanların Paraya Olan Tutum, Kariyer Bağlılığı ve Kariyer Tatmin Düzeyleri Arasındaki İlişki: Otel İşletmelerinde Bir Araştırma \\ (The Relationship between Attitude towards Money, Career Commitment and Career Satisfaction Levels of Employees: A Research on Hotel Enterprises)
}

\section{Emin ARSLAN iD a}

a Tokat Gaziosmanpaşa Üniversitesi, Zile Dinçerler Turizm İşletmeciliği ve Otelcilik Y.O.,Tokat, Türkiye. emin.arslan@gop.edu.tr

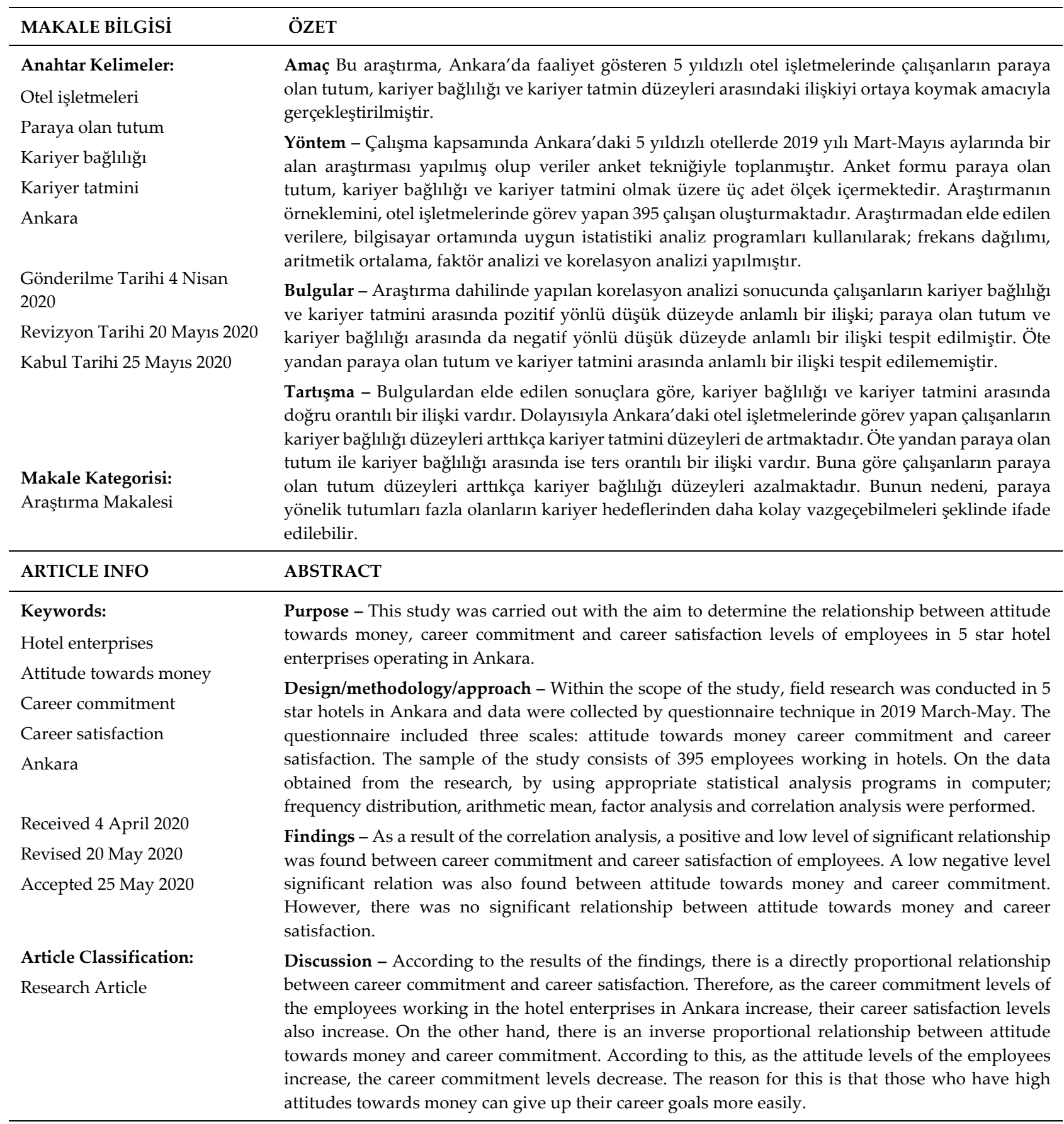

\section{Önerilen Atıf/ Suggested Citation}

Arslan, E. (2020). Çalışanların Paraya Olan Tutum, Kariyer Bağlılığı ve Kariyer Tatmin Düzeyleri Arasındaki İlişki: Otel İşletmelerinde Bir Araştırma, İşletme Araştırmaları Dergisi, 12 (2), 1475-1488. 


\section{Gírìş}

İş dünyasında yaşanan yoğun rekabet ortamında, rakipler karşısında avantaj sağlamaya çalışan işletmeler için insan faktörü en önemli unsurlardan biri olarak öne çıkmaktadır. Güçlü işletmelerin sunduğu mal ya da hizmetin kalitesinin yanında çalışanları vasıtasıyla da nihai tüketicilerin gözünde olumlu bir imaja sahip olduğu söylenilebilir. Çalışma hayatında hem işletmelerin hem de çalışanların karşılıklı olarak birbirlerinden bazı beklentileri bulunmaktadır. Bu bağlamda çalışanların işletmeden beklentilerinde öne çıkan faktörlerden birinin de kariyer olduğu görülmektedir. İşletmelerin çalışanlarına kariyer fırsatları yaratmaları ve bu konuda adil davranmaları çalışanların motive edilmesi açısından önemli bir araçtır. Öte yandan, işletmelerde verimliliğin, kalitenin ve karlılığın arttırılmasında, çalışanlara kariyer imkânı sağlamanın önemi anlaşılmış ve bu durum, kariyer kavramına yönelik birçok akademik araştırmanın (Hall, 1971; Blau, 1985; Colarelli ve Bishop, 1990; Judge ve Bretz, 1994; Seibert vd., 1999; Carson vd., 1999; Yan, 2005; Pan ve Zhou, 2015; Hennekam, 2016) ilgili literatüre kazandırılmasına zemin hazırlamıştır.

Günümüz çalışma hayatında bireylerin devamlı ve karmaşık krizlerin yaşandığı, örgütsel bir çevrede yer almaları, onların zaman içerisinde farklı işler arasında geçiş yapmasına yol açmaktadır. Bu durumda çalışanlar, kariyerlerinde izleyecekleri yolu belirlemek ve kariyer hedeflerine yön vermek için çok fazla sorumluluk üstlenmek zorunda kalmaktadırlar. Bununla beraber, küreselleşme ve teknolojik yenilikler çalışanların kariyer hedeflerinde bazı sapmalara neden olabilmektedir (King, 2004: 113). Dolayısıyla yaşanabilecek bu sapmaların engellenebilmesinde veya en aza indirilebilmesinde, çalışanların kariyer bağlılı̆̆ çok önemli bir rol oynamaktadır. Öte yandan, çalışanların kariyer bağlılığı düzeyleri, meslek hayatında kariyer tatminine de etki yapmaktadır. Bu konuda yapılan araştırmalarda (Tak ve Lim, 2008; Ballout, 2009; Çakmak Otluoğlu, 2014) çalışanlarda var olan yüksek düzeyde bir kariyer bağlllı̆̆ının, onların kariyer tatminini arttırdığına dair bulgular göze çarpmaktadır. İş hayatında yüksek düzeyde kariyer bağlılığı gösteren bireylerin, iş tatmin düzeylerini arttıran bu durum, iş performansına da olumlu yansımaktadır. Bu performans artışı neticesinde bireyler çalıştıkları işletmelerden veya kurumlardan yüksek ücret beklentisine girmektedirler (Kendir ve Özkoç, 2018: 79). Bunun neticesinde yüksek performansla çalışan bireyler zamanla paraya karşı bir tutum da geliştirebilmektedir.

Kariyer bağlllı̆̆1 ve kariyer tatmini ilişkisi turizm alanında zaman zaman akademik araştırmalara konu olmakla birlikte ücret ve para kavramlarıyla birlikte ele alınıp incelenmesi hiç söz konusu olmamıştır. Ancak bu konunun incelenmesi neticesinde alandaki bir boşluğun doldurulacağ 1 ve ilgili literatüre katkı sağlanacağı düşünülmektedir. Bu noktadan hareketle, araştırmanın amacı otel işletmesi çalışanlarında paraya olan tutum, kariyer tatmini ve kariyer bağlılığı ilişkisini araştırmak ve ortaya koymaktır. Dolayısıyla, bu araştırmada, işgören devir hızının oldukça yüksek olduğu otel işletmeleri çalışanlarındaki, kariyer bağlılığı ve kariyer tatmini düzeylerinin tespit edilmesi sayesinde, sezon içerisindeki personel değişikliklerinden kaynaklanan maliyetlerin en aza indirilmesine yönelik işletmeler tarafından tedbirler alınmasına katkı sağlamak hedeflenmektedir.

\section{KAVRAMSAL ÇERÇEVE}

\section{Paraya Olan Tutum Kavramı ve Önemi}

İcadından itibaren tarih boyunca mübadele aracı olarak kullanılan para, en genel anlamıla bir toplumun değer ölçüsü kabul ettiği nesne şeklinde tanımlanmaktadır. Modern dünyada ve ülke ekonomilerinde para, çok büyük rol oynamaktadır. Dünya genelinde ülkeler ekonomilerinin büyüklügüüü belirtirken, bir para birimi üzerinden ifade etmektedir (Aren, 2008: 153). Paranın, değişim nesnesi, hesap birimi ve tasarruf aracı olmak üzere üç temel işlevi bulunmaktadır (Paya, 1994: 18). Bu işlevlerden ilk ikisi paranın asli unsurlarından olup değişimlerin daha kolay bir şekilde yapılmasını sağlama amacına yöneliktir. Diğer bir ifadeyle paranın bu iki işlevi hem mübadele yapmak için kullanılmakta hem de mal veya hizmetlere değer biçme zorluğunu ortadan kaldırmaktadır. Öte yandan üçüncü işlev olan tasarruf, mübadele aracı olma işlevi sayesinde ortaya çıan ikincil bir unsurdur (Aren, 2008: 154).

Bireylerin paraya yönelik geliştirdikleri tutumlar, onların günlük yaşamlarında ve iş hayatında motivasyonlarını, davranışlarını ve iş ilişkilerini önemli bir biçimde etkilemektedir. Bu nedenle para, insanlar için çok önemli bir motivasyon kaynağı olarak algılanmaktadır (Tang vd., 2000: 217). İnsan yaşamında para, duygusal anlam ifade eden önemli bir araçtır. Fizyolojik ihtiyaçlardan yemek, su ve cinsellik paranın en 
önemli rakipleridir. İnsan, yaşamı boyunca pek çok alanda para ile doğrudan ilişkili durumlarla karşılaşmaktadır. Dolayısıyla para kazanmak ve parayı elde etmek için çabalamak, insan yaşamının en önemli uğraşları arasında gösterilebilir. İnsanların paraya karşı tutumunda cinsiyet, yaş ve sosyo-kültürel yapı etkili olmaktadır (Mitchell ve Mickel, 1999: 568).

Paraya olan tutumu; yaş, cinsiyet, kişilik gibi faktörlerin yanında en fazla etkileyen diğer bir faktör de ücrettir. Ücret düzeyi düşük olan çalışanlar para harcama konusunda daha çekingen davranmaya meyillidir ve genellikle iş tatmini açısından parayı bir motivasyon aracı olarak algılarlar. Ücret düzeyi yüksek çalışanlar ise kariyer, sosyal haklar ve takdir görme gibi ücret dışı unsurları motivasyon aracı olarak görebilirler (Ünlüönen ve Arslan, 2012). Dolayısıyla çalışanlarda kariyer bağlılığı, parayla ilişkili olabilecek bir kavram olarak düşünülebilir.

\section{Kariyer Bağlılı̆̆1 Kavramı}

Kariyer kavramı, insanın zaman ve mekân boyutunda organize bir biçimde kat ettiği yol şeklinde tanımlanmaktadır (Van Maanen ve Schein, 1977: 31). Bununla beraber kariyer kavramı, bir çalışanın elde ettiği istihdamla ilgili statüler, roller, faaliyetler ve tecrübeler dizisi olarak ifade edilebilir (Arnold, 1997: 16). Diğer bir ifadeyle kariyer, insanların çalışma hayatında deneyimledikleri işleri ve onlara verilen görevleri nasıl yaptıklarını ifade etmektedir. Bu tanım, iş hayatında kazanılan statüler ve yapılan iş değişiklikleri nedeniyle bireyin çalışma hayatı ve bireysel hayatı ile ilgili geliştirdiği tutumları ve duyguları içermektedir (Noe, 2009: 400). Çalışanların iş hayatında kariyerleri ile ilgili geliştirdiği söz konusu tutumların ve duyguların en önemlilerinden biri de kariyer bağlılığıdır.

Bireylerin kariyer gelişimi ile yakından ilişkili olan kariyer bağlılığı kavramı, birey tarafından seçilen kariyer rolünde çalışmaya yönelik motivasyon aracı olarak tanımlanmaktadır (Hall, 1971: 59). Başka bir tanımda ise kariyer bağlılığı, bireylerin mesleğine veya görevine karşı tutumu şeklinde ifade edilmektedir (Blau, 1985: 280; Blau, 1988: 289; Blau, 1989: 88). Mesleğe veya göreve karşı tutum şeklinde tanımlanan kariyer bağlılığı, bireylerin davranışlarını önemli ölçüde etkileyebilmektedir. Çalışanların yüksek düzeyde kariyer bağlılığına sahip olmasında, bireylerin kendi kariyer hedeflerini sıkı bir şekilde takip etmeleri etkili olmaktadır. Kariyer hedeflerine yüksek düzeyde bağlllık gösteren bireyler, kişisel becerilerini ve tecrübelerini arttırma noktasında daha fazla çaba harcama eğilimi gösterirler (Yan, 2005: 11; İnce ve Kendir, 2016: 20). Söz konusu hususlara daha fazla önem gösteren ve hedeflere ulaşmada ısrarcı olan çalışanlar, yaptıkları işlerde daha yüksek performans sergileyebilmektedir. İşlerinde yüksek performans sergileyen bireyler, daha fazla ücret, terfi ve sosyal haklar ile ödüllendirilmektedir (Çakmak Otluoğlu, 2014: 354).

Bireyler sahip olduğu kariyere geliştirdiği bağlllığı ölçüsünde karşısına çıkan engelleri aşıp kariyer hedeflerini takip ederler. Düşük düzeyde kariyer bağllığı sergileyen çalışan, kariyer engelleriyle mücadele etmek yerine kariyer hedefinde değişiklik yapma yoluna gitmektedir. Örneğin, kariyer hedeflerine son derece bağlı olan bir avukat, karşılaştığı finansal ve mesleki zorlukları aşabilmek için daha fazla mücadele sergileyebilir. Öte yandan kariyer bağlllı̆g düşük olan başka bir avukat ise bireysel olarak zorluklara direnmektense kamu görevini tercih edebilir veya hukuksal işlerle uğraşmaktan kaçınabilir (Colarelli ve Bishop, 1990: 159).

Kariyer bağlılığını etkileyen bazı faktörler bulunmaktadır. Bunlar kişisel ve çevresel faktörler olarak nitelendirilmektedir. Çalışanların aile ortamı, yetişme şartları, sağlık durumları gibi unsurlar kişisel faktörler olarak değerlendirilmektedir. Öte yandan işletmelerin uyguladıkları ücret, sosyal haklar, terfi politikaları ve işyeri çalışma koşulları gibi unsurlar da çevresel faktörler olarak değerlendirilmektedir. Randall (1987: 462) tarafından belirtilen örgütsel bağlılı̆̆ın düzeyleri sıralamasında yüksek düzeyde bağlılık, bireylerin kişisel kariyer hedeflerinin gelişimini ve daha fazla ücret elde edebilmesini olumlu bir şekilde etkilemektedir.

\section{Kariyer Tatmini}

İş hayatında, çalıştığı örgüte ve kariyerine bağlılık sergileyen bireylerin bunun sonucu olarak kariyer tatmini yaşadıkları bilinmektedir. Bu bireylerin iş ve kariyerlerinden vazgeçme olasılığı diğerlerine göre daha düşük düzeyde olmaktadır. Profesyonel yöneticiler, çeşitli eğitimler ve uygulamalar yoluyla çalışanlarını kariyer bağlılı̆̆ı konusunda motive edici olabilirler. Bununla beraber çalıştıkları pozisyonun gereklerini karşılayabilecek yeteneğe sahip olan çalışanların kariyer gelişimlerine odaklanmaları kuvvetle muhtemeldir (Carson vd., 1999: 9). 


\section{E. Arslan 12/2 (2020) 1475-1488}

Literatürde kariyer ve başarı kavramları ile ilişkili olan çalışmalar, genellikle objektif kariyer başarısı üzerinde yoğunlaşmaktadır. Örneğin bireyin işinde yükselmesi, gelir ve mesleki unvan gibi objektif kıstaslar kullanılarak kariyer başarısı kavramı incelenmektedir. Bununla birlikte, bireyin kişisel başarısı üzerine yaptığı değerlendirme sübjektif olabilmektedir. Dolayısıyla bireylerin kariyer başarısını değerlendirirken, onların kariyer gelişimine ve bağlılığına etki eden objektif ve subjektif kavramları incelemenin zorunlu olduğu ortaya çıkmaktadır (Gattiker ve Larwood, 1986: 78).

Birçok araştırmacı tarafından sık sık incelenen kariyer başarısı kavramı; bireyin iş deneyimleri neticesinde ortaya çıkan pozitif psikolojik durumlar, işle ilgili sonuçlar ve kazanımlar olarak tanımlanmaktadır (Judge ve Bretz, 1994; Judge vd., 1995; Seibert vd., 1999; Seibert ve Kraimer, 2001; Abele ve Spurk, 2009a; Abele ve Spurk, 2009b; Pan ve Zhou, 2015; Hennekam, 2016). İlgili literatürde kariyer başarısı kavramı, hem objektif hem de sübjektif açıdan ele alınmaktadır. Objektif kariyer başarısı maaş ve kıdem gibi ölçülebilir kariyer araçlarını ifade ederken, sübjektif kariyer başarısı ise bireylerin kariyerlerinde yaşadıkları tatmin ve başarma gibi duyguları ifade etmektedir (Seibert, vd., 1999: 417). Diğer bir ifadeyle; objektif kariyer başarısı, üçüncü kişiler tarafından gözlemlenebilen durumları kapsarken, sübjektif kariyer başarısı da bireyin kendi algı ve değerlendirmelerini kapsamaktadır. Ücret, para, statü ve terfi objektif kariyer başarısının; kariyer tatmini ve başarı duygusu ise sübjektif kariyer başarısının göstergeleridir (Çakmak Otluoğlu, 2014: 352-353).

Kariyer tatmini kavramı, çalışan bireylerin güncel kariyer başarılarının algılanması ve gelecekteki yükselme beklentileri olarak ifade edilmektedir (Gattiker ve Larwood, 1986: 80; Judge vd., 1995: 487; Nauta vd., 2009: 236). Kariyer tatmini, ücret veya işletmenin sağladığı imkânlardan tatmin gibi somut unsurlara verilmiş bir tepkiye nazaran, kariyer için genelleştirilmiş duygusal bir tepki olarak ortaya çıkmaktadır (Conley, Muncey ve You, 2005: 50). Greenhaus, Parasuraman ve Wormley (1990: 86) çalışanlarda kariyer tatmininin belirlenmesine ilişkin ortaya koydukları ölçekte beş hedeften söz etmektedirler. Bunlar şu şekilde siralanmaktadır:

$>$ Bireyin kendi kariyerinde ulaştığ

$>$ Bireyin genel kariyer hedefleri

$>$ Bireyin kendi gelirine yönelik hedefler

$>$ Bireyin terfiye yönelik hedefler

$>$ Yeni beceriler geliştirmeye yönelik hedefler

İşletmeler açısından kariyer tatmininin değerlendirilmesinde, bireylerin bulundukları pozisyon ve aldıkları ücrete göre içsel bir memnuniyet içerisinde olup olmadıklarına yoğunlaşmak büyük önem arz etmektedir. Öte yandan kariyer tatmininin, çalışanların kariyer bağlllıkları, örgütsel bağlılıkları, örgütsel değişime destek olmaları ve işten ayrılma niyetleriyle ilişkili olduğu, yapılan araştırmaların bulgularından elde edilmiştir (Igbaria, 1991: 141; Carson vd., 1996: 282-285; Vatansever, 2008: 96). Dolayısıyla bu bilgiler ışığında aşağıdaki H1 hipotezi geliştirilmiştir.

H1: Araştırmaya katılan otel işletmesi çalışanlarının kariyer bağlılığı ile kariyer tatmini arasında bir ilişki bulunmaktadır.

\section{Çalışanlarda Paraya Olan Tutum ve Kariyer İlişkisi}

Paraya olan tutum üzerine yapılan ilk araştırmalardan biri, Price (1968) tarafından ABD'de gerçekleştirilmiştir. Bu çalışma daha çok ailelere yönelik olarak planlanmıştır. Ekonomi, psikoloji ve sosyal psikoloji alanlarını ilgilendiren kavramlardan faydalanarak, bir ölçek geliştirmeyi amaçlamaktadır. Paraya karşı bir tutum geliştirmek aslında tüm insanlara has bir özelliktir. Öte yandan çalışanların geliştirdiği paraya olan tutumlar da özellikle işletme veya kurum içerisindeki davranışlarını ve iş performanslarını etkileyebilmektedir (Ünlüönen ve Arslan, 2012: 177).

Çalışanların meslek hayatlarındaki kariyer bağlılıkları ve kariyer tatminleri ücret, gelir, yaş, cinsiyet, çalışma şartları vb. birçok faktörden etkilenebilmektedir (Tak ve Lim 2008; Kendir ve Özkoç, 2018). Bu faktörler arasında yer alan ücret, paraya olan tutum ile ilişkili bir kavram olarak gösterilebilir. Ancak literatür incelendiğinde paraya olan tutum ve kariyer kavramlarının ilişkisini araştıran turizm alanında hiçbir çalışma yer almamaktadır. Diğer taraftan işletme alanında üniversite öğrencileri üzerine Süer vd. (2017) tarafından yapılmış bir araştırma mevcuttur. Bu araştırmanın sonuçlarında da paraya tutumu fazla olan üniversite öğrencilerinin kariyerinde yüksek gelirli ve dolgun maaşlı işleri hedeflediği tespit edilmiştir. 
Yukarıdaki bilgiler ışığında, otel işletmelerinde çalışanların kariyer bağlılığı ve kariyer tatmini kavramlarının paraya olan tutumla ilişkisi olabileceği düşünülmektedir. Literatürde yer alan ilgili araştırmaların sonuçları bu konunun incelenmesini değerli kılmaktadır. Dolayısıyla bu konunun araştırılması amacıyla geliştirilen $\mathrm{H} 2$ ve H3 hipotezleri aşağıda yer almaktadır.

H2: Araştırmaya katılan otel işletmesi çalışanlarının paraya olan tutumları ile kariyer bağl1lı̆̆ı arasında anlamlı bir ilişki bulunmaktadır.

H3: Araştırmaya katılan otel işletmesi çalışanlarının paraya olan tutumları ile kariyer tatmini arasında anlamlı bir ilişki bulunmaktadır.

\section{YÖNTEM}

Betimsel nitelikte olan araştırmanın modelinde amaç, eldeki mevcut problemi, bu probleme ilişkin değişkenleri ve değişkenler arasındaki ilişkileri tanımlayarak bir konudaki varolan durumu araştırmaktır (Ural ve Kılıç, 2006: 19). Bu noktadan hareketle araştırmanın uygulama aşamasına geçebilmek için bir ölçme aracı kullanılmıştır. Ölçme aracının oluşturulması safhasında ilk olarak konuyla ilgili yapılmış olan çalışmalardan ve daha önce oluşturulmuş olan ölçeklerden yararlanılmıştır. Araştırmada kullanılan ölçme aracı 3 farklı ölçekten oluşmaktadır. Bu ölçekler: Paraya Olan Tutum; Tang (1992), Furnham (1996), Tang vd. (1997), Mitchell ve Mickel (1999) araştırmalarından derlenen ve Arslan (2011)'ın da çalışmasında kullandığ 1 ölçek 18 ifade ve tek boyuttan oluşmaktadır. Kariyer Tatmini; Greenhaus, Parasuraman ve Wormley (1990) tarafından geliştirilen ölçek 5 ifade ve tek boyuttan, Kariyer Bağ lılığı; Blau (1988) tarafından geliştirilen ölçek 7 ifade ve tek boyuttan oluşmaktadır.

Araştırmanın veri çözümleme sürecinde 5'li Likert şeklinde derecelendirilen ankette araştırma kapsamındaki beş yıldızlı otel işletmelerinde çalışanların belirtilen her bir ifadeye katılım dereceleri; Hiç Katılmıyorum=1 ve Tamamen Katılıyorum=5 arasında puanlandırılarak değerlendirilmiştir. Anketlerden elde edilen verilere frekans dağılımı, güvenilirlik analizi, faktör analizi ve korelasyon analizi gibi istatistik yöntemleri uygulanmıştır. Araştırma evrenini Ankara'da faaliyet gösteren beş yıldızlı otellerdeki çalışanlar oluşturmaktadır. Bunun nedeni araştırma yapılan dönemde (2019 Mart-Mayıs) genellikle şehir içi otellerin açık olması ve Ankara'nın yeterli düzeyde şehir içi oteline sahip olmasıdır. Ankara' daki beş yıldızlı otel sayısı ve yatak kapasitesi hakkında Ankara İl Kültür ve Turizm Müdürlüğü ile iletişime geçilmiş ve Ankara' da 2019 yılında 26 adet beş yıldızlı turizm işletme belgeli otelin 11.042 adet yatağının olduğu bilgisi edinilmiştir. TÜROFED (Türkiye Otelciler Federasyonu) tarafından 2010 yılında turizm istihdamı üzerine yapılmış olan bir çalışmaya göre beş yıldızlı otellerde 3,08 yatak başına 1 personel düşmektedir (TÜROFED, 2010). Tüm bu veriler ışığında Ankara'da beş yıldızlı otellerde yaklaşık 3.085 çalışanın istihdam edildiği hesaplanmaktadır.

Araştırma örnekleminin belirlenmesinde kolayda örnekleme yönteminden yararlanılmıştır. Örneklem sayısının hesaplanmasında Yamane (2001), örneklem formülü kullanılmıştır (Yamane, 2001: 116). Bu formüle göre araştırma evreni 3.085 olarak kabul edildiğinde araştırma örneklemi de $\% 95$ güven seviyesinde 342 olarak ortaya çıkmaktadır. Araştırmaya Ankara'dan 2019 yılı Mart-Mayıs ayları arasında 9 adet beş yıldızlı otel işletmesi katılmıştır. Bu işletmelere toplamda 450 adet anket formu topla bırak yöntemiyle bırakılmıştır. Bırakılan anket formlarından 410 adedi geri dönmüştür. Bunların 395 tanesi değerlendirmeye alınmıştır. Geri kalan 15 adet anket formu ise eksik ve tutarsız olduğundan dolayı değerlendirmeye alınmamıştır.

\section{BULGULAR}


E. Arslan 12/2 (2020) 1475-1488

Tablo 1. Katılımcıların Demografik Özelliklerine İlişkin Frekans Dağılımları

\begin{tabular}{|c|c|c|}
\hline Demografik Özellikler & $f$ & $\%$ \\
\hline $\begin{array}{l}\text { Cinsiyet } \\
\text { Erkek } \\
\text { Kadın } \\
\text { Toplam }\end{array}$ & $\begin{array}{l}246 \\
149 \\
395 \\
\end{array}$ & $\begin{array}{l}62,3 \\
37,7 \\
100 \\
\end{array}$ \\
\hline $\begin{array}{l}\text { Gelir (Aylk) } \\
1000 \text { TL ve altı } \\
\text { 1001-2000 TL } \\
\text { 2001-3000 TL } \\
\text { 3001 TL ve üzeri } \\
\text { Toplam }\end{array}$ & $\begin{array}{c}77 \\
151 \\
128 \\
39 \\
395\end{array}$ & $\begin{array}{c}19,5 \\
38,2 \\
32,4 \\
9,9 \\
100,0\end{array}$ \\
\hline $\begin{array}{l}\text { Yaş } \\
18-24 \\
25-31 \\
32-38 \\
39 \text { ve Üzeri } \\
\text { Toplam } \\
\end{array}$ & $\begin{array}{c}61 \\
135 \\
97 \\
102 \\
395\end{array}$ & $\begin{array}{r}15,4 \\
34,2 \\
24,6 \\
25,8 \\
100,0 \\
\end{array}$ \\
\hline $\begin{array}{l}\text { Medeni Hal } \\
\text { Evli } \\
\text { Bekâr } \\
\text { Toplam }\end{array}$ & $\begin{array}{l}191 \\
204 \\
395\end{array}$ & $\begin{array}{c}48,4 \\
51,6 \\
100,0\end{array}$ \\
\hline $\begin{array}{l}\text { Ĕ̈itim } \\
\text { İlköğretim } \\
\text { Lise } \\
\text { Önlisans } \\
\text { Lisans } \\
\text { Toplam }\end{array}$ & $\begin{array}{c}22 \\
149 \\
95 \\
129 \\
395\end{array}$ & $\begin{array}{c}5,6 \\
37,7 \\
24,1 \\
32,7 \\
100,0\end{array}$ \\
\hline $\begin{array}{l}\text { Çalışılan Departman } \\
\text { Önbüro } \\
\text { Kat Hizmetleri } \\
\text { Yiyecek ve İçecek } \\
\text { Diğer } \\
\text { Toplam }\end{array}$ & $\begin{array}{c}114 \\
49 \\
101 \\
131 \\
395\end{array}$ & $\begin{array}{c}28,9 \\
12,4 \\
25,5 \\
33,2 \\
100,0\end{array}$ \\
\hline $\begin{array}{l}\text { Sektörde Çalışma Süresi } \\
1 \text { Ylldan Az } \\
1-5 \text { Yıl } \\
6-10 \text { Yil } \\
11 \text { Yll ve Üzeri } \\
\text { Toplam }\end{array}$ & $\begin{array}{c}45 \\
137 \\
111 \\
102 \\
395\end{array}$ & $\begin{array}{r}11,4 \\
34,7 \\
28,1 \\
25,8 \\
100,0 \\
\end{array}$ \\
\hline $\begin{array}{l}\text { İşletmede Çalışma Süresi } \\
1 \text { Yıldan Az } \\
\text { 1-5 Y1l } \\
6-10 Y_{11} \\
\text { 11-15 Yıl } \\
\text { Toplam }\end{array}$ & $\begin{array}{c}97 \\
176 \\
68 \\
54 \\
395\end{array}$ & $\begin{array}{r}24,6 \\
44,6 \\
17,2 \\
13,6 \\
100,0\end{array}$ \\
\hline
\end{tabular}

Tablo 1'de araştırmaya katılanların demografik özelliklerine ilişkin frekans dağılımları incelendiğinde, büyük çoğunluğunu erkek katılımcılar $(n=246 ; \% 62,3)$ oluşturmaktadır. Kadınların oranı ise $(n=149 ; \% 37,7)$ erkeklerden daha azdır. Ankete cevap verenlerin gelir düzeylerinin 1001-3000 TL (n=279; \%70,6) arasında olduğu ve medeni durumları bakımından bekâr $(n=204 ; \% 51,6)$ oldukları görülmektedir. Araştırmaya katılanlar 25-38 (n=232; \%58,8) yaş aralığında yoğunlaşmaktadır. Katılımcılar eğitim seviyelerine göre en fazla 
lise mezunlarından ( $\mathrm{n}=149 ; \% 37,7)$ oluşmaktadır. Anketi cevaplayanların çalıştığı departmanlar göz önünde bulundurulduğunda, en fazla önbüro ve yiyecek - içecek departmanından ( $\mathrm{n}=215 ; \% 54,4)$ katılımın sağlandığ1 görülmektedir. Turizm sektöründe çalışma süreleri bakımından 1-10 yıl arası ( $\mathrm{n}=248 ; \% 62,8)$, işletmede çalışma süreleri bakımından ise en fazla 1-5 yıl arası çalışanların (n=176; \%44,6) katılımı görülmektedir.

Tablo 2: Paraya Olan Tutum Ölçeğinin Faktör Analizi Sonuçları

\begin{tabular}{|c|c|c|c|c|}
\hline İFADELER & 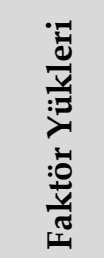 & 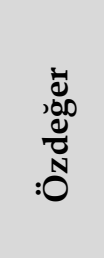 & 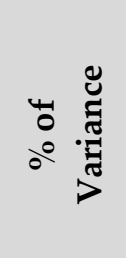 & 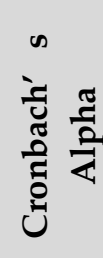 \\
\hline Paraya Olan Tutum & & 6,905 & 57,542 & 0,930 \\
\hline Para her şeyi satın alabilir & 0,781 & & & \\
\hline Para güç demektir & 0,810 & & & \\
\hline Para beni mutlu eden şeylerin başında gelir & 0,852 & & & \\
\hline Bahşiş veren müşteriye daha fazla ilgi gösteririm & 0,643 & & & \\
\hline Para başarı sembolüdür & 0,770 & & & \\
\hline Para bir motivasyon aracıdır & 0,785 & & & \\
\hline Paraya çok fazla değer veririm & 0,823 & & & \\
\hline Paranın mutluluğu arttırdığına inanıyorum & 0,851 & & & \\
\hline Para bütün problemleri çözer & 0,788 & & & \\
\hline Daha fazla gelir elde etmek için her yolu denerim & 0,593 & & & \\
\hline Parasız mutlu olamam & 0,688 & & & \\
\hline Para için gerekirse ek iş yaparım & 0,665 & & & \\
\hline Toplam Ölçek Güvenilirliği ve Varyansı & & & 57,542 & 0,930 \\
\hline
\end{tabular}

Tablo 2' de Paraya Olan Tutum ölçeğine ait faktör analizi sonuçları yer almaktadır. Ölçekten faktör yükü değeri uygun olmayan altı ifade çıkarılmış ve faktör analizi tekrarlanmıştır. Nihai faktör analizi sonuçlarına göre, en başta 18 ifadeli olan ölçekten, faktör yükü düşük olan 6 adet ifade çıkarılmıştır. Kalan 12 maddenin faktör çözümünün açıklayıcılığı incelendiğinde, tek boyutlu faktör çözümünün toplam varyansın $\% 57,542$ 'sini açılayabildiği görülmektedir. Sosyal bilimlerde faktör analizinde açıklanan varyans oranının tek faktörlü ölçeklerde \%30'un üzerinde olması yeterli kabul edilmektedir (Büyüköztürk, 2008: 125). Ayrıca örneklem büyüklügünün yeterliliğini gösteren Kaiser-Meyer-Olkin (KMO) testi sonucuna bakıldığında 0,932 değeri mükemmel değer olarak kabul edilebilir. Eroğlu'na (2009: 322) göre KMO değerleri ve yorumları şu şekilde belirtilmiştir: 0,50' nin altı değer kabul edilemez, 0,50 değer zayıf, 0,60 değer orta, 0,70 değer iyi, 0,80 değer çok iyi ve 0,90 değer mükemmeldir. Bartlett küresellik testi sonucuna göre de Sig. 0,000 (p<0,05) çıkması bu araştırmadaki ifadelerin faktör analizi için uygun olduğunu göstermektedir. Analiz sonucu ve Paraya Olan Tutum ölçeğinin güvenilirlik katsayısı Alpha $(\alpha)=0,930$ olarak tespit edilmiştir. Alpha katsayısının $0,60 \leq \alpha<0,80$ arasında olması ölçeğin oldukça güvenilir olduğuna, katsayının $0,80 \leq \alpha<1,00$ arasında olması ise ölçeğin yüksek derecede güvenilir olduğuna işaret etmektedir (Akgül ve Çevik, 2005: 436; Kayış, 2009: 405). Dolayısıyla araştırmada veri toplama aracı olarak kullanılan ölçeğin güvenilirlik düzeyinin yüksek derecede güvenilir olduğu söylenebilir.

Tablo 3: Kariyer Tatmini Ölçeğinin Faktör Analizi Sonuçları 


\begin{tabular}{|c|c|c|c|c|}
\hline İFADELER & 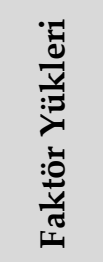 & 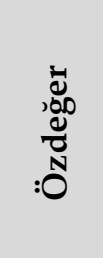 & 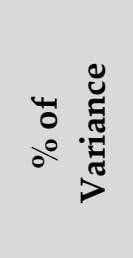 & 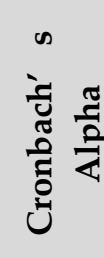 \\
\hline Kariyer Tatmini & & 3,849 & 76,988 & 0,924 \\
\hline Kariyerimde ulaştığım başarı beni tatmin ediyor & 0,877 & & & \\
\hline $\begin{array}{l}\text { Tüm kariyer hedeflerime yönelik gösterdiğim ilerleme beni tatmin } \\
\text { ediyor }\end{array}$ & 0,932 & & & \\
\hline Gelir hedeflerime yönelik gösterdiğim ilerleme beni tatmin ediyor & 0,900 & & & \\
\hline Terfi hedeflerime yönelik gösterdiğim ilerleme beni tatmin ediyor & 0,890 & & & \\
\hline $\begin{array}{l}\text { Kariyer hedeflerim doğrultusunda yeni yetenekler geliştirmek beni } \\
\text { tatmin ediyor }\end{array}$ & 0,781 & & & \\
\hline Toplam Ölçek Güvenilirliği ve Varyansı & & & 76,988 & 0,924 \\
\hline
\end{tabular}

Tablo 3'te Kariyer Tatmini ölçeğine ait faktör analizi sonuçları görülmektedir. Buna göre, faktör çözümünün açıklayıcılığı incelendiğinde tek boyutlu faktör çözümünün toplam varyansın \%76,988'ini açıklayabildiği görülmektedir. Örneklem büyüklüğünün yeterliliğini gösteren Kaiser-Meyer-Olkin (KMO) testi sonucuna bakıldığında 0,875 değeri çok iyi değer olarak kabul edilebilir.

Bartlett küresellik testi sonucuna göre de Sig. 0,000 ( $<<0,05)$ çıkması bu araştırmadaki ifadelerin faktör analizi için uygun olduğunu göstermektedir. İlgili ölçeğin güvenilirlik katsayısı Alpha $(\alpha)=0,924$ olarak belirlenmiştir. Dolayısıyla araştırmada veri toplama aracı olarak kullanılan ölçeğin güvenilirlik düzeyinin yüksek derecede güvenilir olduğu söylenebilir.

Tablo 4: Kariyer Bağl1lı̆̆ı Ölçeğinin Faktör Analizi Sonuçları

\begin{tabular}{|c|c|c|c|c|}
\hline İFADELER & 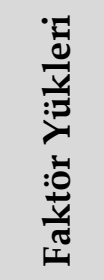 & 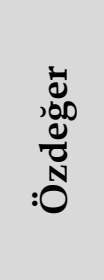 & 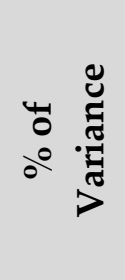 & 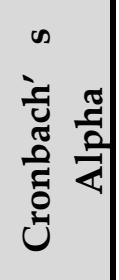 \\
\hline Kariyer Bağlılığ1 & & 4,668 & 66,685 & 0,916 \\
\hline $\begin{array}{l}\text { Şu anda çalıştığım işten, başka bir işi seçme ve aynı ücreti alma şansım } \\
\text { olsaydı diğer işi seçerdim. (R) }\end{array}$ & 0,770 & & & \\
\hline $\begin{array}{l}\text { Kesinlikle şu anda çalıştı̆̆ım iş üzerine bir kariyer planı yapmak } \\
\text { istiyorum }\end{array}$ & 0,847 & & & \\
\hline $\begin{array}{l}\text { Geçmişe dönme şansım olsa, şu anda çalıştığım işte olmak istemezdim. } \\
\text { (R) }\end{array}$ & 0,832 & & & \\
\hline $\begin{array}{l}\text { İhtiyaç duyduğum parayı çalışmadan elde etmiş olsam bile, şu anda } \\
\text { çalıştığım işi yapmaya yine devam ederdim }\end{array}$ & 0,786 & & & \\
\hline Şu anda çalıştığım işimi vazgeçemeyecek kadar çok seviyorum & 0,864 & & & \\
\hline Şu anda çalıştığım iş, bir ömür boyunca çalışılabilecek ideal bir iştir & 0,821 & & & \\
\hline Şu anda çalıştığım işe başladığım anda hayal kırıklığına uğradım. (R) & 0,791 & & & \\
\hline Toplam Ölçek Güvenilirliği ve Varyansı & & & 66,685 & 0,916 \\
\hline
\end{tabular}

Not: $R$ ile gösterilen ifadeler ters kodlanmıştır. 
Tablo 4'te Kariyer Bağhllı̆̆ı ölçeğine ait faktör analizi sonuçları görülmektedir. Buna göre, faktör çözümünün açılayıcılığı incelendiğinde tek boyutlu faktör çözümünün toplam varyansın \%66,685'ini açıklayabildiği görülmektedir. Örneklem büyüklügünün yeterliliğini gösteren Kaiser-Meyer-Olkin (KMO) testi sonucuna bakıldığında 0,865 değeri çok iyi değer olarak kabul edilebilir.

Bartlett küresellik testi sonucuna göre de Sig. 0,000 $(\mathrm{p}<0,05)$ çıkması bu araştırmadaki ifadelerin faktör analizi için uygun olduğunu göstermektedir. İlgili ölçeğin güvenilirlik katsayısı Alpha $(\alpha)=0,916$ olarak tespit edilmiştir. Dolayısıyla araştırmada veri toplama aracı olarak kullanılan ölçeğin güvenilirlik düzeyinin yüksek derecede güvenilir olduğu söylenebilir.

Tablo 5: Ölçeklere İlişkin Çarpıklık ve Basıklık Katsayıları

\begin{tabular}{lccc}
\hline & POT & KT & KB \\
\hline N Çarpıklık (Skewness) & 395 & 395 & 395 \\
Std. Hata (Çarpıklık) &,- 111 &, 075 &,- 211 \\
Basıklık (Kurtosis) &, 123 &, 123 &, 123 \\
Std. Hata (Basıklık) &,- 975 &,- 730 & $-1,170$ \\
\hline
\end{tabular}

Not: POT: Paraya Olan Tutum; KT: Kariyer Tatmini; KB: Kariyer Bağllı̆ı̆ı

Verilerin normal dağılım gösterip göstermediğine yönelik analiz sonuçları Tablo 5'te yer almaktadır. Tabachnick ve Fidell (2013)'e göre basıklık ve çarpıklık katsayılarının \pm 2 arasında olması verilerin normal dağılım gösterdiğine işaret etmektedir. Analiz sonucunda ortaya çıkan katsayıların \pm 2 arasında olduğu görülmektedir. Buna göre değişkenlere ait verilerin normal dağılım gösterdiği söylenilebilir.

Tablo 6. Paraya Olan Tutuma İlişkin Aritmetik Ortalama ve Standart Sapma Değerleri

\begin{tabular}{|l|c|c|}
\hline IFFDELER & $\begin{array}{c}\text { Aritmetik } \\
\text { Ortalama }\end{array}$ & $\begin{array}{c}\text { Standart } \\
\text { Sapma (ss) }\end{array}$ \\
\hline Paraya Olan Tutum & 2,79 & 1,52 \\
\hline Para her şeyi satın alabilir & 3,56 & 1,30 \\
\hline Para güç demektir & 3,08 & 1,35 \\
\hline Para beni mutlu eden şeylerin başında gelir & 2,75 & 1,42 \\
\hline Bahşiş veren müşteriye daha fazla ilgi gösteririm & 3,26 & 1,20 \\
\hline Para başarı sembolüdür & 3,47 & 1,14 \\
\hline Para bir motivasyon aracıdır & 2,76 & 1,24 \\
\hline Paraya çok fazla değer veririm & 3,28 & 1,27 \\
\hline Paranın mutluluğu arttırdığına inanıyorum & 2,86 & 1,33 \\
\hline Para bütün problemleri çözer & 2,37 & 1,21 \\
\hline Daha fazla gelir elde etmek için her yolu denerim & 2,34 & 1,27 \\
\hline Parasız mutlu olamam & 2,90 & 1,36 \\
\hline Para için gerekirse ek iş yaparım & 2,95 & 0,98 \\
\hline Genel Ortalama & & \\
\hline
\end{tabular}

Tablo 6'da araştırmaya katılanların paraya olan tutumlarına ilişkin aritmetik ortalama ve standart sapma değerleri yer almaktadır. Buna göre ilgili ölçekte $\bar{X}=3,56$ ile "para güç demektir" ifadesi en yüksek ortalama puana sahip olurken, "parasız mutlu olamam" ifadesi $\bar{X}=2,34$ ile en düşük ortalama puana sahip olmuştur. Öte yandan otel işletmesi çalışanlarının paraya olan tutumlarına ilişkin genel aritmetik ortalamanın $\bar{X}=2,95$ ile orta değerin altında gerçekleştiği ortaya çıkmaktadır. 
Tablo 7. Kariyer Tatminine İlişkin Aritmetik Ortalama ve Standart Sapma Değerleri

\begin{tabular}{|l|c|c|}
\hline IFADELER & $\begin{array}{c}\text { Aritmetik } \\
\text { Ortalama }\end{array}$ & $\begin{array}{c}\text { Standart } \\
\text { Sapma (ss) }\end{array}$ \\
\hline Kariyer Tatmini & 2,79 & 1,24 \\
\hline Kariyerimde ulaştı̆̆ım başarı beni tatmin ediyor & 2,85 & 1,22 \\
\hline Tüm kariyer hedeflerime yönelik gösterdiğim ilerleme beni tatmin ediyor & 2,75 & 1,16 \\
\hline Gelir hedeflerime yönelik gösterdiğim ilerleme beni tatmin ediyor & $\mathbf{2 , 7 1}$ & 1,22 \\
\hline Terfi hedeflerime yönelik gösterdiğim ilerleme beni tatmin ediyor & $\mathbf{3 , 3 0}$ & 1,24 \\
\hline $\begin{array}{l}\text { Kariyer hedeflerim doğrultusunda yeni yetenekler geliştirmek beni tatmin } \\
\text { ediyor }\end{array}$ & 2,88 & 1,07 \\
\hline Genel Ortalama &
\end{tabular}

Tablo 7'de otel çalışanlarının kariyer tatminlerine ilişkin aritmetik ortalama ve standart sapma değerleri yer almaktadır. Buna göre ilgili ölçekte $\bar{X}=3,30$ ile "kariyer hedeflerim doğrultusunda yeni yetenekler geliştirmek beni tatmin ediyor" ifadesi en yüksek ortalama puana sahip olurken, "terfi hedeflerime yönelik gösterdiğgim ilerleme beni tatmin ediyor" ifadesi $\bar{X}=2,71$ ile en düşük ortalama puana sahip olmuştur. Öte yandan çalışanların kariyer tatminlerine ilişkin genel aritmetik ortalamanın $\bar{X}=2,88$ ile orta değerin altında gerçekleştiği ortaya çıkmaktadır.

Tablo 8. Kariyer Bağlılığına İlişkin Aritmetik Ortalama ve Standart Sapma Değerleri

\begin{tabular}{|l|c|c|}
\hline İFADELER & $\begin{array}{c}\text { Aritmetik } \\
\text { Ortalama }\end{array}$ & $\begin{array}{c}\text { Standart } \\
\text { Sapma (ss) }\end{array}$ \\
\hline Kariyer Bağlıı̆ı̆ı & 2,51 & 1,29 \\
\hline $\begin{array}{l}\text { Şu anda çalıştığım işten, başka bir işi seçme ve aynı ücreti alma şansım } \\
\text { olsaydı diğer işi seçerdim. (R) }\end{array}$ & $\mathbf{3 , 2 0}$ & 1,42 \\
\hline Kesinlikle şu anda çalıştığım iş üzerine bir kariyer planı yapmak istiyorum & 2,54 & 1,44 \\
\hline Geçmişe dönme şansım olsa, şu anda çalıştığım işte olmak istemezdim. (R) & 2,82 & 1,47 \\
\hline $\begin{array}{l}\text { İhtiyaç duyduğum parayı çalı̧̧madan elde etmiş olsam bile, şu anda } \\
\text { çalıştığım işi yapmaya yine devam ederdim }\end{array}$ & 2,83 & 1,32 \\
\hline Şu anda çalıştığım işimi vazgeçemeyecek kadar çok seviyorum & 2,79 & 1,33 \\
\hline Şu anda çalıştığım iş, bir ömür boyunca çalışılabilecek ideal bir iştir & $\mathbf{2 , 1 2}$ & 1,23 \\
\hline Şu anda çalıştığım işe başladığım anda hayal kırıklığına uğradım. (R) & 2,69 & 1,36 \\
\hline Genel Ortalama & & \\
\hline
\end{tabular}

Not: (R) ile belirtilen ifadeler ters kodlanan ifadelerdir.

Tablo 8'de katılımcıların kariyer bağlılıklarına ilişkin aritmetik ortalama ve standart sapma değerleri yer almaktadır. Buna göre ilgili ölçekte $\bar{X}=3,20$ ile "kesinlikle şu anda çalıştığım iş üzerine bir kariyer planı yapmak istiyorum" ifadesi en yüksek ortalama puana sahip olurken, "şu anda çalıştı̆̆ım işe başladığım anda hayal kırıklı̆̆ına uğradım." ifadesi $\bar{X}=2,12$ ile en düşük ortalama puana sahip olmuştur. Öte yandan çalışanların kariyer bağlılıklarına ilişkin genel aritmetik ortalamanın $\bar{X}=2,69$ ile orta değerin altında gerçekleştiği ortaya çıkmaktadır. 
Tablo 9: Değişkenler Arası Korelasyon Matrisi

\begin{tabular}{|l|c|c|c|}
\hline Boyutlar (n=395) & $\begin{array}{c}\text { Paraya Olan } \\
\text { Tutum }\end{array}$ & $\begin{array}{c}\text { Kariyer } \\
\text { Tatmini }\end{array}$ & $\begin{array}{c}\text { Kariyer } \\
\text { Bağlılığ }\end{array}$ \\
\hline $\begin{array}{l}\text { Paraya Olan Tutum } \\
\text { (pearson korelasyon kaysayısı) }\end{array}$ & 1 & 1 & 1 \\
\hline $\begin{array}{l}\text { Kariyer Tatmini } \\
\text { (pearson korelasyon katsayısı) }\end{array}$ &, 040 &, $189^{* *}$ & 1 \\
\hline $\begin{array}{l}\text { Kariyer Bağlılığı } \\
\text { (pearson korelasyon katsayısı) }\end{array}$ &,$- 167^{* *}$ & & \\
\hline
\end{tabular}

${ }^{* *} p<0,01$

Tablo 9' da yer alan korelasyon analizi sonuçlarında, pearson korelasyon katsayısının 1,00 olması, mükemmel bir pozitif ilişkiyi ifade ederken, $-1,00$ olması ise mükemmel bir negatif ilişkiyi ifade etmektedir. 0,70-1,00 arasında olması yüksek, 0,70-0,30 arasında olması orta, 0,30-0,00 arasında olması ise düşük düzeyde bir ilişki olarak tanımlanabilir. Değişkenler arasındaki ilişkiler şu şekilde yorumlanmaktadır; iki değişken arasında pozitif yönlü bir ilişki olması deneklerin $X$ değişkenine ait değerlerinin artması durumunda $Y$ değişkenine ait değerlerinde artması anlamına gelmektedir. Negatif yönlü ilişkide ise $X$ değişkenine ait değerler artarken, $Y$ değişkenine ait değerler düşmektedir (Büyüköztürk, 2008: 32).

Tablo 9'a göre, kariyer bağlılı̆̆ı ile kariyer tatmini arasında (pearson korelasyon katsayısı $\rightarrow 0,189$ ) pozitif yönlü düşük düzeyde anlamlı bir ilişki vardır. Bu nedenle, H1: “Araştırmaya katılan otel işletmesi çalışanlarının kariyer bağgllığı ile kariyer tatmini arasında bir ilişki bulunmaktadır" hipotezi kabul edilmiştir. Bununla beraber paraya olan tutum ile kariyer bağllı̆̆̆ arasında ise (pearson korelasyon katsayısı $\rightarrow-0,167$ ) negatif yönlü düşük düzeyde anlamlı bir ilişki vardır. Buna göre $\mathbf{H 2 : ~ " A r a s ̧ t ı r m a y a ~ k a t ı l a n ~ o t e l ~ i s ̧ l e t m e s i ~ c ̧ a l ı s ̧ a n l a r ı n ı n ~ p a r a y a ~ o l a n ~ t u t u m l a r ı ~ i l e ~}$ kariyer bağglılığı arasında anlamlı bir ilişki bulunmaktadır" hipotezi de kabul edilmiştir. Ancak paraya olan tutum ile kariyer tatmini arasında (pearson korelasyon katsayısı $\rightarrow 0,040$ ) anlamlı bir ilişki bulunmamaktadır. Dolayısıyla H3: "Araştırmaya katılan otel işletmesi çalışanlarının paraya olan tutumları ile kariyer tatmini arasında anlamlı bir ilişki bulunmaktadır" hipotezi kabul edilmemiştir.

\section{SONUÇ ve TARTIŞMA}

Turizm sektörünün ana aktörlerinden biri olan otel işletmelerinde hizmet kalitesinin en vazgeçilmez ve en temel belirleyicisi olan faktör çalışanlardır. Otel çalışanlarının sürekliliğini sağlamak, kariyerlerini planlayabilecekleri ve ilerleyebilecekleri uygun örgüt iklimini yaratmak hem çalışanlar hem de otel işletmeleri açısından göz ardı edilmemesi gereken bir durumdur. Ankara'daki 5 yıldızlı otel işletmesi çalışanlarının paraya olan tutumlarının kariyer bağlılığı ve kariyer tatmini ile ilişkisinin incelendiği bu araştırmaya toplamda 9 otel işletmesinden 395 çalışan katılmıştır.

Araştırmadan elde edilen bulgulardan ilki otel işletmelerinde çalışanların kariyer bağlılıkları ile kariyer tatmini arasında düşük düzeyde pozitif yönlü anlamlı bir ilişkinin yapılan korelasyon analizine göre tespit edilmesidir. Buradan hareketle araştırmaya katılan çalışanların kariyer bağlılık düzeyleri arttıkça kariyer tatmin düzeylerinin de arttığı söylenilebilir. Bu sonuç daha önce alanda yapılan ilgili araştırmaların (Tak ve Lim, 2008; Ballout, 2009; Çakmak Otluoğlu, 2014; Kendir ve Özkoç, 2018) bulgularılyla da benzeşmektedir. Araştırmanın ikinci ve çalışmayı farklı kılan en önemli bulgusu, otel işletmelerinde çalışanların paraya olan tutumları ile kariyer bağlılıkları arasında düşük düzeyde ve negatif yönlü anlamlı bir ilişkinin yapılan korelasyon analizinde ortaya çıkmasıdır. Buna göre araştırmaya katılan çalışanların paraya olan tutum düzeyleri arttıkça kariyer bağlılıkları azalmaktadır. Araştırmadan elde edilen bu bulgu, alanda daha önce yapılmış olan hiçbir araştırmada elde edilmediğinden dolayı bir karşılaştırma yapmak olanaksızdır. Ancak söz konusu bulgunun sebebi olarak Süer vd. (2017: 536)'nin araştırmasından elde edilen "parayı güç ve prestij aracı olarak görenlerin kariyer hedeflerinden ziyade dolgun maaşı ve hızl terfiyi önemsemeleri" sonucu gösterilebilir. Öte yandan bu araştırmada çalışanların paraya olan tutumlarıyla kariyer tatminleri arasında anlamlı bir ilişki bulunamamıştır. Araştırma kapsamında elde edilen bulgulardan yola çıkarak şu öneriler geliştirilmiştir:

> Kariyer bağ lılığı, hem çalışanların hem de çalışanlarına önem veren işletmelerin üzerinde mutlaka durması gereken bir kavramdır. Dolayısıyla çalışanların ve otel işletmelerinin bu konuda doğru hedefler 
belirleyerek, stratejik planlamalar yapmaları gerekmektedir. Doğru atılmış kariyer temelleri, gelecekte çalışanlar açısından kariyer tatmini ve başarı sağlarken, işletmeler açısından da hizmet kalitesi, verimlilik ve karlılık sağlayabilecektir.

> Paraya olan tutumu yüksek olan çalışanları tespit etmek ve bu konularda bilinçlendirmek, onların kariyer hedeflerinden vazgeçmelerini hatta işten ayrılmalarını bile önleyebilecektir. Dolayısıyla otel işletmeleri, en büyük sorunlarından biri olan sürekli personel değişimlerinden uğradıkları zararı azaltabilecektir.

Araştırmanın bazı sınırlılıkları bulunmaktadır. Zaman kısıtlılığı 2019 yılının Mart-Mayıs ayları dönemini kapsamaktadır. Öte yandan yer kısıtlılığı ise Ankara'daki 5 yıldızlı otel işletmeleri ile sınırlı kalmaktadır. Dolayısıyla gelecekte araştırma yapacak akademisyenler, bu sınırlılıkları göz önünde bulundurarak kıyı veya yaz-kış sezonluk otellerde bu araştırmayı yapabilirler. Daha farklı sonuçlar elde edilme imkânı olabilir. Çünkü şehir içi otellerde personel devir hızı kıyı otellerine göre nispeten düşük düzeydedir. Bununla beraber Türkiye' de turizm alanında yapılmış sınırlı sayıdaki araştırmadan biri olması nedeniyle önem arz eden bu çalışmanın bulgularından, işverenler, insan kaynakları, kariyer danışmanları ve rehberlik uzmanları fayda sağlayabilirler.

\section{KAYNAKÇA}

Abele, A.E. \& Spurk, D. (2009a). The longitudinal impact of self-efficacy and career goals on objective and subjective career success. Journal of Vocational Behavior. 74: 53-62.

Abele, A. E. \& Spurk, D. (2009b). How do objective and subjective career success interrelate over time? Journal of Occupational and Organizational Psychology. 82: 803-824.

Akgül, A., Çevik, O. (2005). İstatistiksel Analiz Teknikleri “SPSS’te İşletme Yönetimi Uygulamaları”. Emek Ofset. Ankara

Aren, S. (2008). İstihdam Para ve İktisadi Politika. İmge Kitabevi. Ankara.

Arnold, J. (1997). Managing Careers Into The 21st Century. Paul Chapman Publishing, London.

Arslan, E. (2011). Otel İşletmelerinde Çalışanların Paraya Olan Tutumunun Mesleki Etik Değerler Açısından İncelenmesi. Gazi Üniversitesi, Eğitim Bilimleri Enstitüsü, Yayınlanmamış Yüksek Lisans Tezi, Ankara.

Ballout, H.I. (2009). Career commitment and career success: moderating role of self-efficacy. Career Development International. 14(7): 655-670.

Blau, G.J. (1985). The measurement and prediction of career commitment. Journal of Occupational Psychology. 58: 277-288.

Blau, G.J. (1988). Further exploring the meaning and measurement of career commitment. Journal of Vocational Behavior. 32: 284-297.

Blau. G. (1989). Testing the generalizability of a career commitment measure and its impact on employee turnover. Journal of Vocational Behavior. 35: 88-103.

Büyüköztürk, Ş. (2008). Veri Analizi El Kitabı. Pegem Yayınları. Ankara.

Carson, K.D., Carson, P.P., Phillips, J.S. \& Roe, C.W. (1996). A career entrenchment model: Theoretical development and empirical outcomes. Journal of Career Development. 22(4): 273-286.

Carson, K.D., Carson, P.P., Roe, C.W., Birkenmeier, B.J. \& Philips, J.S. (1999). Four commitment profiles and their relationships to empowerment, service recovery, and work attitudes. Public Personnel Management 28(1): 1-13.

Colarelli, S.M. \& Bishop, R.C. (1990). Career commitment: Functions, correlates, and management. Group \& Organization Studies 15(2): 158-176.

Conley, S., Muncey, D.E., You, S. (2005). Standards-Based evaluation and teacher career satisfaction: A structural equation modeling analysis. Journal of Personnel Evaluation in Education. 18(1): 39-65. 


\section{E. Arslan 12/2 (2020) 1475-1488}

Çakmak Otluoğlu, K.Ö. (2014). Kariyer bağlılı̆̆ının kariyer başarısı üzerindeki etkisinin incelenmesi üzerine bir araştırma. Yönetim ve Ekonomi Araştırmaları Dergisi. 23: 350-363.

Eroğlu, A. (2009). Faktör Analizi. Şeref Kalaycı (Ed.), SPSS Uygulamalı Çok Değişkenli İstatistik Teknikleri içinde (ss. 321-331). Ankara: Asil Yayın Dağıtım.

Furnham, A. (1996). Attitudinal Correlates and Demographic Predictors of Monetary Beliefs and Behaviors. Journal of Organizational Behavior. 17: 375 - 388.

Gattiker, U.E. \& Larwood, L. (1986) Subjective career success: A study of managers and support personnel. Journal of Business and Psychology. 1(2): 78-94.

Greenhaus, J.H., Parasuraman, S. \& Wormley, W.M. (1990). Effects of race on organizational experiences, job performance evaluations, and career outcomes. The Academy of Management Journal. 33(1): 64-86.

Hall, D.T. (1971). A theoretical model of career subidentity development in organizational settings. Organizational Behavior and Human Performance. 6: 50-76.

Hennekam, S. (2016). Vitality of older workers and its relationship with performance, career satisfaction and career success. Management $\mathcal{E}$ Avenir. 83: 15-32.

Igbaria, M. (1991). Job performance of MIS professionals: An examination of the antecedents and consequences. Journal of Engineering and Technology Management. 8: 141-171.

İnce, C. \& Kendir, H. (2016). Turizm Öğrencilerinin Kariyer Beklentilerine Yönelik Düşünceleri: Stajyer Öğrenciler Örneği. International Journal of Academic Value Studies. 2(4): 13-23.

Judge, T.A. \& Bretz, R.D. (1994). Political influence behavior and career success. Journal of Management. 20(1): 43-65.

Judge, T.A., Cable, D.M., Boudreau, J.W. \& Bretz, R.D. (1995). An empirical investigation of the predictors of executive career success. Personnel Psychology. 48: 485-519.

Kayış, A. (2009). Güvenilirlik Analizi. Şeref Kalaycı (Ed.) SPSS Uygulamalı Çok Değişkenli İstatistik Teknikleri içinde (ss. 403-419). Ankara: Asil Yayın Dağıtım.

Kendir, H. \& Özkoç, A.G. (2018). Otel İşletmelerinde Çalışanların Kariyer Tatmini ve Kariyer Bağlılığı İlişkisinde Öz Yeterliliğin Rolü. Journal of Tourism and Gastronomy Studies. 6(4): 78-112.

King, Z. (2004). Career self-management: its nature, causes and consequences. Journal of Vocational Behavior. 65: 112-133.

Mitchell, T. R. \& Mickel, A. E. (1999). The Meaning of Money: An Individual - Difference Perspective. Academy of Management Review. 24(3): 568 - 578.

Nauta, A., Vianen, A., Heijden, B., Dam, K. \& Willemsen, M. (2009). Understanding the factors that promote employability orientation: The impact of employability culture, career satisfaction, and role breadth self-efficacy. Journal of Occupational and Organizational Psychology. 82: 233-251.

Noe, R.A. (2009). İnsan Kaynaklarının Eğitimi \& Geliştirilmesi, çev. Canan Çetin. Beta Yayıncılık. İstanbul.

Pan. J. \& Zhou, W. (2015). How do employees construe their career success: An improved measure of subjective career success. International Journal of Selection and Assessment. 23(1): 45-58.

Paya, M.M. (1994). Para Teorisi ve Para Politikası. Filiz Kitabevi. İstanbul.

Price, D.Z. (1968). A technique for analyzing the economic value system. Journal of Marriage and the Family. 30(3): 467-472.

Randall, D.M. (1987). Commitment and the organization: The organization man revisited. The Academy of Management Review. 12(3): 460-471.

Seibert, S.E., Crant, J.M. \& Kraimer, M.L. (1999). Proactive personality and career success. Journal of Applied Psychology. 84(3): 416-427. 
E. Arslan 12/2 (2020) 1475-1488

Seibert, S.E. \& Kraimer, M.L. (2001). The five-factor model of personality and career success. Journal of Vocational Behavior. 58: 1-21.

Süer, Ö., Baklacı, H.F. \& Kocaer, E. (2017). Para tutumunun kariyer hedefleri üzerindeki etkisi: üniversite öğrencileri üzerinde bir araştırma. Ege Akademik Bakış. 17(4): 527-537.

Tak, J. \& Lim, B. (2008). The differences in career-related variables between temporary and permanent employees in information technology companies in Korea. Journal of Career Development. 34(4): 423437.

Tang, P-T.L. (1992). The Meaning of Money Revisited Source. Journal of Organizational Behavior. 13(2): 197-202.

Tang, P-T. L., Arocas, R.L. \& Whiteside, H.D. (1997). Attitude Toward Money and Demographic Variables as Related to Income and Life Satisfaction: US vs. SPAIN, 22. Annual Conference of International Association for Research in Economic Psychology, Valencia, Spain, September 15-18.

Tang, P-T. L., Kim, J.K. \& Tang, D.S-H. (2000). Does Attitude Toward Money Moderate The Relationship Between Intrinsic Jobsatisfaction And Voluntary Turnover? Human Relations. 53: 213-245.

Türofed, (2010). Turizm Raporu, Ekim. Ekin Grubu Araştırma Birimi. İstanbul.

Ural, A. \& Kılıç, İ. (2006). Bilimsel Araştırma Süreci ve Spss ile Veri Analizi. Detay Yayıncılık. Ankara.

Ünlüönen, K. \& Arslan, E. (2012). Otel işletmelerinde çalışanların paraya olan tutumunun mesleki etik değerler açısından incelenmesi. Elektronik Sosyal Bilimler Dergisi. 11(40): 173-187.

Van Maanen, J. \& Schein, E.H. (1977). Career Development. J. R. Hackman and J. L. Shuttle (Eds.), Improving Life at Work: Behavioral science approaches to organizational change in (pp. 30-95) (Goodyear Pub. Co, California).

Vatansever, Ç. (2008). Work and non-work life balance, and its relation to organizational commitment and career satisfaction. Doktora Tezi. Marmara Üniversitesi Sosyal Bilimler Enstitüsü, İngilizce İşletme Anabilim Dalı. İstanbul.

Yamane, T. (2001). Temel Örnekleme Yöntemleri. (1. Baskı). (Çev. A. Esin, M. A. Bakır, C. Aydın ve E. Gürbüzsel). Literatür Yayıncilik. İstanbul.

Yan, Y.W. (2005). Antecedents and outcomes of employees' participation in development activity. Doctoral Dissertation, Hong Kong Baptist University. Hong Kong. 